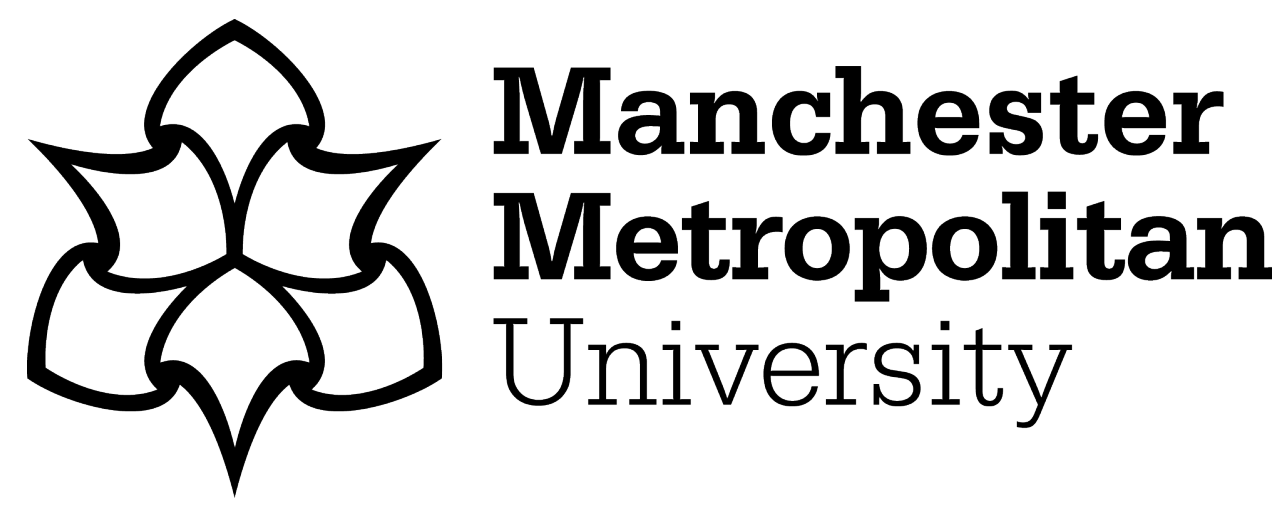

Carradus, Angela, Zozimo, Ricardo and Discua Cruz, Allan (2020) Exploring a Faith-Led Open-Systems Perspective of Stewardship in Family Businesses. Journal of Business Ethics, 163 (4). pp. 701-714. ISSN 0167-4544

Downloaded from: https://e-space.mmu.ac.uk/625138/

Version: Accepted Version

Publisher: Springer Science and Business Media LLC

DOI: https://doi.org/10.1007/s10551-019-04387-2

Please cite the published version 


\title{
Exploring a Faith-Led Open-Systems Perspective of Stewardship in Family Businesses
}

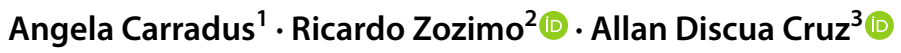

Received: 6 November 2018 / Accepted: 4 December 2019

(c) Springer Nature B.V. 2019

\begin{abstract}
The purpose of this study is to examine how faith-led practices in family firms affect organizational stewardship. Current studies highlight the relevance of religious adherence for family businesses, yet provide limited understanding of how this shapes the key traits of these organizations. Drawing on six autobiographies of family business leaders who openly express their adherence to their faith, and adopting an open-systems analysis of these autobiographies, we demonstrate that faith-led values influence organizational and leadership practices. Overall, our study suggests that the influence of religious beliefs in the organizational practices of family businesses have greater repercussions than previously thought. By introducing a faith-led approach to stewardship, we enrich the theoretical discussion around stewardship and the relevance of religion in family business.
\end{abstract}

Keywords Spiritual open-systems · Stewardship · Family business · Organizational practices · Extended kinship network · Faith-led business

\section{Introduction}

The role of religion as one dimension of stewardship relies "very much on personal characteristics such as values, honesty, generosity, sacrifice, and discipline" (Le Breton-Miller and Miller 2018, p. 233), influencing multiple areas of the family business. Stewardship theory assumes a relationshipbased system with a focus on non-financial goals, individuals serving the organizational good (Davis et al. 1997), the intrinsic desire to pursue collective goals, and relying on trust as a control mechanism (Madison et al. 2016). Recent studies argue that stewardship in business can serve as an

Electronic supplementary material The online version of this article (https://doi.org/10.1007/s10551-019-04387-2) contains supplementary material, which is available to authorized users.

Ricardo Zozimo

ricardo.zozimo@novasbe.pt

Allan Discua Cruz

a.discuacruz@lancaster.ac.uk

1 Manchester Metropolitan University, Manchester, UK

2 NOVA School of Business and Economics, Carcavelos, Portugal

3 Lancaster University Management School, Lancaster, UK organizing mechanism (Hernandez 2008; Segal and Lehrer 2012). Family businesses are found to have a stronger stewardship climate than their non-family counterparts, fostering employee engagement with policies, practices, and procedures, adopting pro-organizational values (Neubaum et al. 2017), and affecting the governance of these firms (James et al. 2017).

Family businesses are a unique context characterized by the co-existence of individual, family, and business systems (Kepner 1983; Habbershon et al. 2003; Litz 2008; Astrachan 2010) in which the daily enactment of work and home are often "inextricably intertwined" (Aldrich and Cliff 2003; Hamilton 2006; Fletcher 2010). Traditionally, the influence of religion is linked to aspects of ethical and moral decision-making in the business in which individuals with strong faith-led behaviours hold a position of influence (Weaver and Agle 2002). Yet, while extensive research has hinted at the importance of religion in family firms, we still know little about how and why organizational practices in family firms change (Wong et al. 2018; Kellermanns 2013), and how stewardship relates to faith-led practices within the firm (Dodd and Dyck 2015; Discua Cruz 2013).

To explore this complex intertwining between organizational practices and stewardship, we build on the opensystems perspective of Pieper and Klein (2007). In family 
firms, family and business subsystems influence each other, shaping the firm's unique character (Habbershon et al. 2003; Litz 2008; Pieper and Klein 2007). We argue that an opensystems methodology, enabling a wider but more detailed analysis of each subsystem, allows describing how religious faith can shape organizational practices (Smith-Acuña 2011) and theorizing on its influence on stewardship.

Due to the exploratory nature of this study, we address a broad research question: How do faith-led practices in family firms affect organizational stewardship? We draw on an open-systems framework to help us interpret written autobiographies. Recent research has advocated autobiography as a source of insights that enable advancing understanding of family firms over time (Hjorth and Dawson 2016). Thus, we empirically draw on six family businesses and their autobiographies: Ouimet (Ouimet and Semen 2013), Cardone (Cardone 2009), Chick-fil-A (Cathy 2007), Interstate Batteries (Miller and Hosier 1996), Hobby Lobby (Green and Merrill 2010), and Mary Kay (Ash and Pendleton 2008). The selected autobiographies help to illustrate how faith shapes organizational practices in family business and therefore stewardship.

Our study thus contributes to scholarship by unveiling how faith affects stewardship in family businesses. Conceptualizing stewardship from the perspective of individuals involved in the family business (Davis et al. 2010), our study extends and complements earlier research framing stewardship in the psychological and sociological perspectives (Henssen et al. 2014; Hernandez 2012; Wade-Benzoni et al. 2008).

The remainder of the paper is structured as follows. We first discuss stewardship and religion in the family business context, then introduce the systems perspective to investigate the organizational practices of faith-led leaders in family businesses. We then explain the methodology, discuss our findings, describe a faith-led family systems model and its implications for stewardship theory. Last, we offer our conclusions and suggest some future research avenues.

\section{Stewardship and Religion in the Family Business Context}

Family businesses are the heartbeat of the global economy and are currently the predominant organizational form around the world (Melin et al. 2014). Researchers agree that one of the key characteristics of family business is that family and business objectives are often difficult to separate (Astrachan 2003, 2010; Fletcher 2002; Hamilton 2013). Recent studies contend that stewardship practices and behaviours are more likely to be evident in family than non-family firms (Neubaum et al. 2017; Madison et al. 2016; Dodd and Dyck 2015). Dodd and Dyck (2015) argue that family firms may place greater emphasis on stewardship due to their interpersonal relationships, relational and socioemotional value, identity and long-term commitment to their firm, enhanced personal reputation through stewardship activities, and more likely to be inherently moral as a result of shared cultural values and religious convictions. Thus, family businesses are an ideal context to examine the integration of faith under a stewardship lens.

The stewardship perspective recognizes that family business owners and managers are not always self-serving but align their goals and motivations with those they serve in the whole organization (Davis et al. 2010). Such perspective suggests that leaders may develop organizational practices that benefit the family firm when policies foster stewardship behaviours (Zahra et al. 2008; James et al. 2017). It could be argued that committed family leaders and non-family employees can achieve this by engaging in constant and positive interactions framed in faith.

In this regard, Neubaum et al. (2017, p. 38) introduced the stewardship climate perspective as "the extent to which individuals perceive that their firm's policies, practices, and procedures foster stewardship behaviours and stewardship values, which are widely shared across the organization". The central tenets of stewardship climate are that organizations reflect the leader's values, and that steward leaders will design and govern their firms to elicit stewardship behaviours from others within the organization. Exchanges between family business stewards and individuals achieve this by creating a situation of reciprocal stewardship that permeates the organization (Neubaum et al. 2017, p. 38). Family businesses with a stewardship climate emphasize intrinsic motivation, organizational identification, use of personal forms of power, collectivism, low power distance, and involvement orientation. Neubaum et al. (2017) demonstrate that family businesses have a stronger stewardship climate than non-family firms, suggesting that their benefits are realized in the policies, practices, and procedures that promote sharing the stewardship values across the organization.

Neubaum et al. (2017) call for studies to explore the extent to which family firms are likely to be inherently moral or inclined to remain within the boundaries of moral behaviour as a result of their shared religious convictions. Inspired by Le Breton-Miller and Miller (2018) and Discua Cruz $(2013,2018)$, we observe that among the many dimensions that affect stewardship, religion has the capacity to encourage the behaviour associated with stewardship benefits by fostering honesty and trust, and reducing agency costs. This distinction is based on studies exploring stewardship theory (Davis et al. 1997), and stewardship behaviour arising from the values, beliefs, and sentiments of business leaders (Hernandez 2008, 2012) in family business (Davis et al. 2010; Neubaum et al. 2017). 
The stewardship concept is not disconnected from Christian literature, pointing towards the "balancing of interests" of responsibility to God and to fellow man (Rossouw 1994). A Christian perspective of stewardship in family firms calls on the owners to look at the business and everything in it from God's perspective according to Biblical scripture (Joshua 24: 15; Leviticus 25: 23; Psalms 50: 10-12; Haggai 2: 8; Ecclesiastes 5: 19; James 1: 17, NRSV). In this perspective, Christians are stewards of the committed resources by the legitimacy and authority of God (Cafferky 2012), thus devising organizational practices to ensure the wellbeing of everyone and everything in order to honour God (Deuteronomy 6: 5, 10: 1; Psalm 22: 231 Isaiah 42: 12; Luke 12: 42-48; Ephesians 4: 28).

To believers, God is a legitimate and authoritative guide for behaviour, and an important stakeholder in the decisions made for the firm, its operations, and practices (Schwartz 2006), thus adopting organizational practices that make them accountable for their actions to God and the larger community (Discua Cruz 2015). This suggests an emphasis on servant-like leadership, trust, and vocation (Smith 2005; Rossouw 1994; Cafferky 2012), and the relevance of a systems view in the stewardship perspective (Neubaum et al. 2017).

\section{A Systems Perspective on Organizational Practices of Faith-Led Family Businesses}

A key feature of family businesses is that they reflect the idiosyncratic views of families that often have religious beliefs that may influence the organizational context, and hence the way the firm operates or pursues its objectives over time (Paterson et al. 2013). Family businesses must develop practices that allow members to work together to achieve their goals and objectives, and interact with external actors. Compared to other types of firms, family businesses may derive their organizational practices from the interaction between the family and the business subsystems (Kepner 1983). Organizational practices express the way businesses pursue their objectives, the shared routines and knowledge that support the provision of products and services, allowing the members to meet their customers' needs (Beatson et al. 2008). The long-term perspective that tends to characterize family firms encourages the development of organizational practices as part of a survival strategy implicitly influenced by the values, objectives, and beliefs held by family members (Lumpkin and Brigham 2011; Sorenson 2013).

Several studies have identified and lauded the existence of Christian owned and operated businesses (Chan-Serafin et al. 2012; Wong et al. 2018). One of the most comprehensive definitions of a business that aims to uphold the Christian faith is one that "declare[s] their belief in, and active pursuit of, the successful merging of biblical principles with business activities" (Ibrahim and Angelidis 2005, p. 187). A Christian emphasis in organizations may imply that many of the key decision-makers have a strong faith-based set of values, and see working in a faith-led organization as an opportunity to apply these values consistently (Weaver and Agle 2002). This would naturally apply to the way the business operates and how it perceives relationships (Mabey et al. 2017; Discua Cruz 2015). These previously explored concepts (Lynn and Wallace 2001) underscore that those in control of a family business may frame pro-organizational practices in an idiosyncratic, relational way. However, additional empirical evidence is needed to show how such practices shape family-owned businesses.

To investigate the issues related to diverse yet interconnected organizational practices within family businesses, scholars commonly use a systems perspective. The system theorists Ludwig von Bertalanffy suggested, "in order to understand an organized whole we must know both the parts and the relations between them" (Bertalanffy 1972, p. 411). Whilst generally applied to family therapy, systems theory has more recently been adopted by family business scholars to explore many aspects and key features of family businesses (Kepner 1983), including organizational culture (Martins and Terblanche 2003), relational communication (Schlippe and Frank 2013), and wealth creation (Habbershon et al. 2003).

Kepner (1983) highlights the importance of developing our understanding of the interaction between the family subsystem and the firm's development. Building on this perspective can contribute to our understanding of stewardship in a faith-led family firm where the relationship with God is integral. Schlippe and Frank (2013, p. 387) argue that a systems approach enables considering the nuanced interaction between the "individual, subsystems, family business and environment". These studies highlight an arrangement of elements in family firms that are interdependent and interconnected to form a purposeful whole.

Pieper and Klein (2007), based on a comprehensive review of systems theory, propose four structural areas of a family business system. First, the family subsystem, which aims to explore the influence of individual beliefs on relationship-building and organizational practices with extended networks of employees, customers, competitors, suppliers, and other stakeholders. Second, the business, described as an "organization that processes inputs from the environment and returns some product or service" (Pieper and Klein 2007, p. 306). Third, ownership structures that consider legal and psychological dimensions, as well as voting infrastructure and/or firm capital. Last, the management subsystem encompasses the top management team leadership, and relationships between employees and managers, which may be guided by stewardship behaviours. 
These systems are the means by which value is created and delivered to stakeholders. We build on Pieper and Klein's (2007) conceptualization of an open-systems approach to investigate how the faith-centred stewardship perspective of an individual leader affects the business structure and practices. We consider this in the context of the environment in which the family business exists and operates, drawing on the perspective of God as the managerial stakeholder or ultimate CEO (Schwartz 2006, p. 292). We argue that the individual's belief in the family as part of the family of God is embedded in the family subsystem. Consequently, a faith-led family approach influences the organizational behaviours and structures of the day-to-day stewardship of faith-led family businesses.

Few mainstream perspectives adopt such a nuanced method to understand the complex layers of a family business system influenced by faith-led stewardship behaviours and relationships. This is especially important when examining the influence that faith has on the owner-manager, and consequently the way in which the family business operates over time.

\section{Methodology}

\section{Research Design}

Seeking to capture in-depth personal data illustrating the complex and diverse relationships between spirituality, ownership, and organizational enactment, we rely on written narratives in the form of autobiographies. Autobiographies are distinct from biographies as they rely on primary data to develop insights on the origins of ideas (Ford et al. 2003), such as the leader's vocation, the challenges of translating this vocation into organizational practices, and the successes and failures of their approach. Autobiographies can be useful to understand family business, as they "shed light on the relational dynamics of how family and business, as well as family members, are inextricably interconnected" (Dawson and Hjorth 2012, p. 350). Following earlier work drawing on autobiographies (Dawson and Hjorth 2012), our research design enabled collecting rich, personal data from a number of individuals with different backgrounds and religious vocations.

Whilst we accept that relying on autobiographical accounts is a particular and somewhat unusual form of research design, previous studies in family business (Dawson and Hjorth 2012), entrepreneurship (Reveley 2010; Smith 2005), and leadership (Humphreys et al. 2012; Westley and Mintzberg 1989) indicate the possibility of rigour in such design. There are, of course, limitations to using autobiographies, as they may "intentionally or unintentionally be written with an agenda or purpose in mind" (Mathias and Smith
2016, p. 208). Considering our research interest in faith-led businesses, we believe that this is an advantage, as autobiographies allow free expression of religious beliefs. In addition, we also took note of possible "correspondence bias" whereby family business leaders attribute success to internal rather than external causes (Mathias and Smith 2016). In this regard, for triangulation and contextualization, we complemented the use of autobiographies with additional data (see Table 1). Furthermore, we remained vigilant to the possibility of social desirability bias where autobiographies are written in a manner that will be viewed favourably by others (Mathias and Smith 2016). Consequently, we were mindful of the interpretation limitations associated with social desirability and the influence on the nature of the claims made. In sum, we borrow from Goss et al. (2011, p. 218) who state that, "any such problems are outweighed by the advantages that this material offers in terms of depth and duration".

\section{Sampling}

Our sampling strategy was purposeful and intrinsically linked to our research question (Patton 2002). While numerous studies consider the topic of faith and work (Gundolf and Filser 2013; Ewest 2015), less has been published on the enactment of individual and organizational spirituality as part of stewardship in family businesses. We therefore began by gathering a worldwide list of resources associated with the topics of religion, spirituality, and family business. One of our main concerns was identifying family businesses that were openly Christian, made their Christian faith public, and pronounced that faith was part of their leadership, managerial practices, and decision-making processes. We worked through many manuscripts distinguishing family business cases from others, which led us to identify six Christian family businesses in America.

We believe our sample of cases is appropriate due to the diversity and detailed accounts of successful and unsuccessful practices. Our cases also include an enhanced, sometimes even intimate degree of personal and deep reflections (Boyle and Parry 2007) that underpin our theoretical narrative in relation to stewardship. Finally, by presenting rich data from a diverse sample of different industries and religious backgrounds, we contribute with a conceptualization that is richer and more accepting of religious and spiritual differences. Our final sample of autobiographies as well as additional material used can be found in Table 1 .

\section{Data Collection}

Autobiographies are the main source of our data, offering a temporal account of how individuals build and shape organizations (Mathias and Smith 2016) in openly Christian family businesses. While the autobiographies vary in 


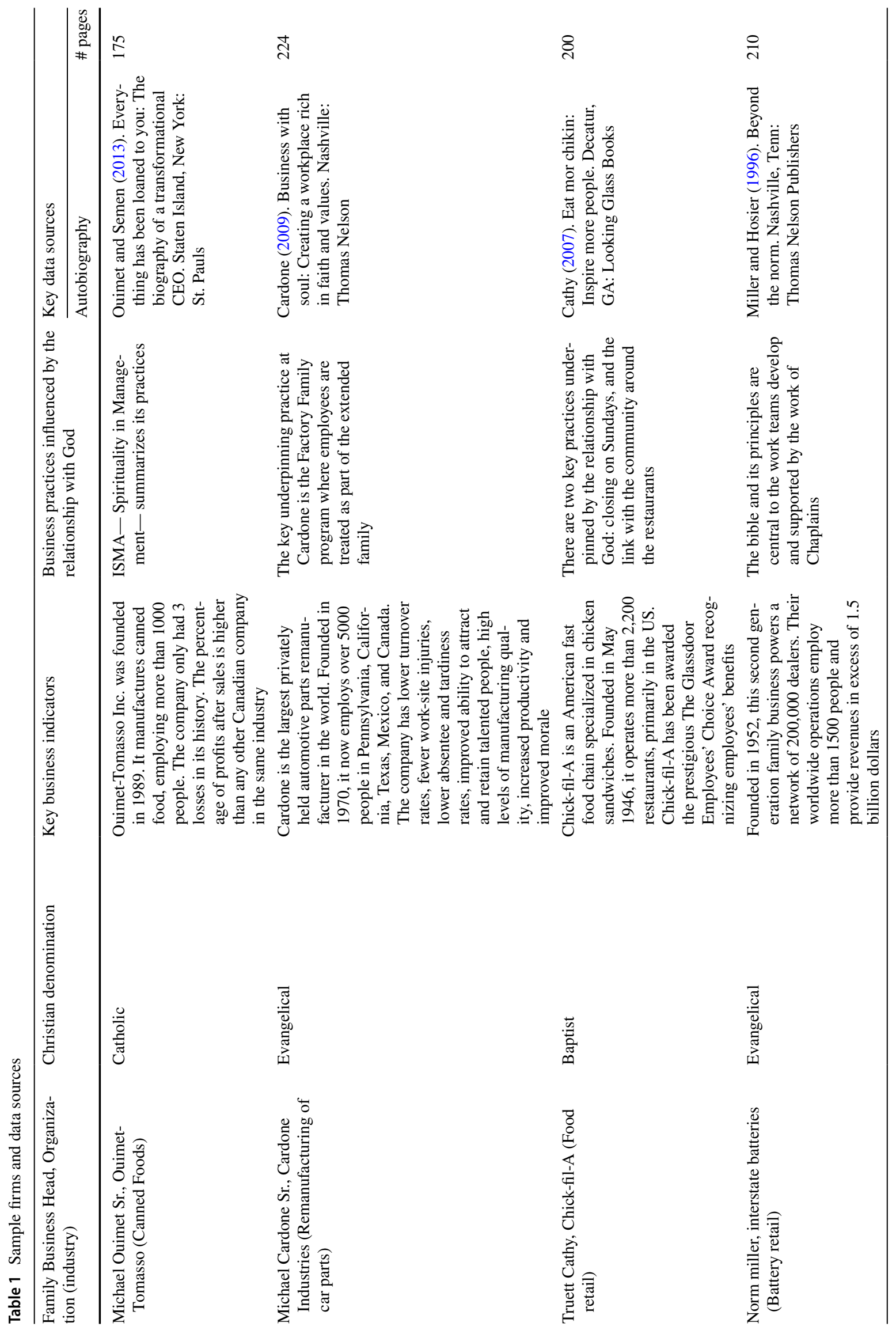


length, internal organization, and range of topics, they all cover the personal and organizational journey of each family business. We analysed more than 1271 pages across the six autobiographies.

While each autobiography is different, some common themes emerged. For example, all offered detailed examples of "God-centred" organizational practices, why these emerged and made sense, and how the leaders implemented them. The process dimension is of particular interest, as it allowed us to link leaders' behaviours to the changes that occur when a family business becomes a faith-led family business system. Finally, based on the personal and reflective substance of the autobiographies, we sought additional data including financial reports, workforce absenteeism, and productivity levels. This allowed examining the changes in the family business subsystems and understanding how putting God first influences stewardship.

For each case, we supplemented the autobiographies with other publicly available sources (Mathias and Smith 2016). We included company reports and manuals, published research or teaching cases, and online interviews or talks on online video platforms. This additional data (see Table $1 \mathrm{~b})^{1}$ allowed us to contextualize each family business and deepen our understanding of their faith-led processes and practices.

\section{Data Analysis}

We adopted Dawson and Hjorth's (2012) framework to generate insights from the family business narratives. In line with their recommendations, our analytical process followed three steps. The first was explication, which consists of summarizing the stories after reading and re-reading the autobiographies and taking extensive notes. We did this individually over a number of months and regularly met to discuss our views of each of the six narratives. Table 2 reports the outcome of our collective analysis.

The second step was explanation in which we interwove our reading of the autobiographies with the spirituality and family business literature. We built on established perspectives to inform our interpretation but were mindful not to be constrained by these (Hamilton 2006). In building interpretations, each member of the team read widely and explored different theory building avenues. During this phase, additional sources of data were included to enrich the emerging insights.

The third step was exploration in which we came together as a team to discuss the "so what" question. As we jointly moved between theory and data, we adopted an open-systems perspective to guide our analytical work. This led to

$\overline{1 \text { Table S1b }}$ can be found in the supplementary files attached to this paper. 


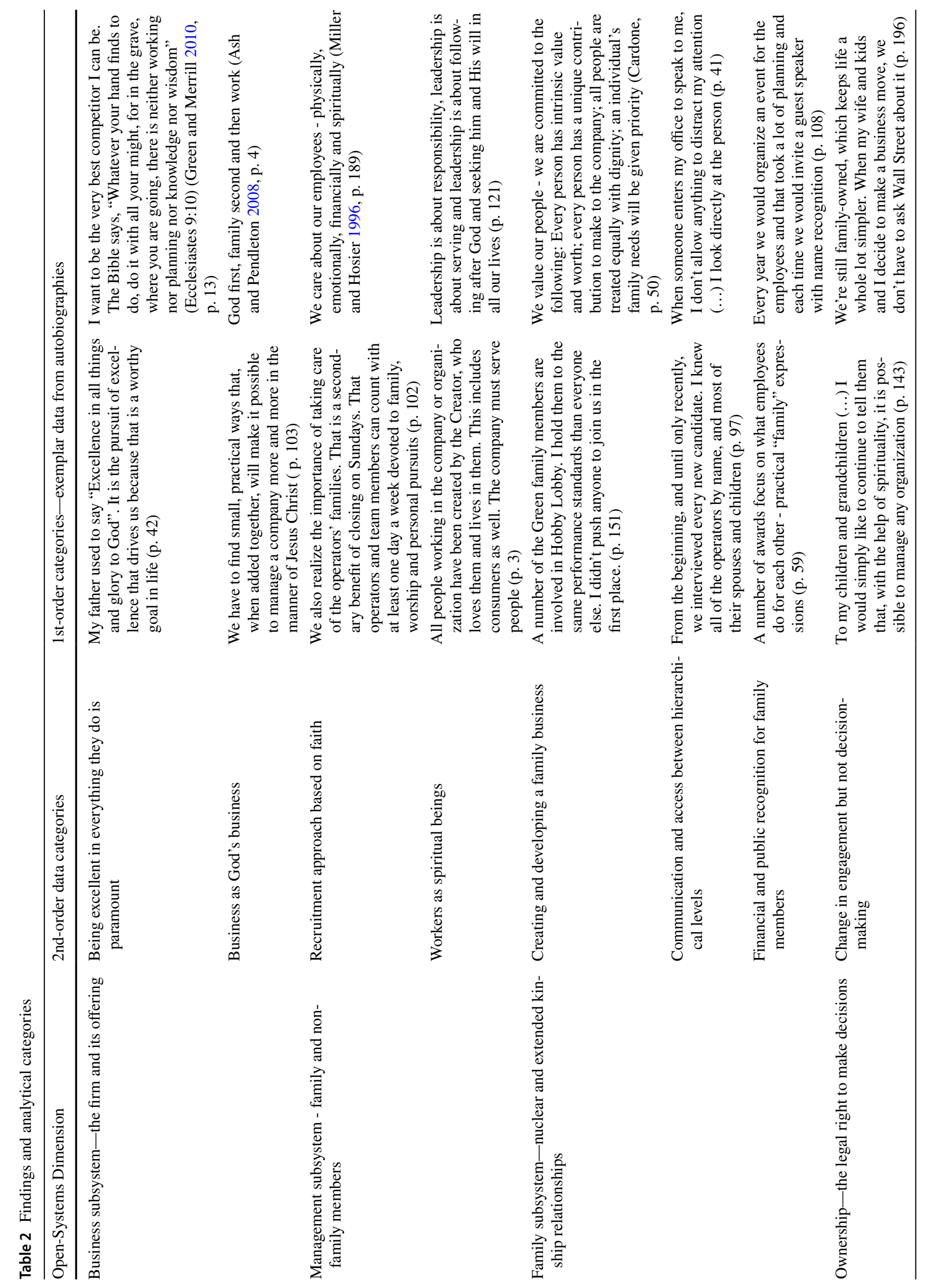


linking our work with other dimensions of the family business literature, such as ownership and management (Astrachan 2010). For our analysis, we produced a coding tree illustrating each dimension of the family business system affected by the relationship with God (Table 2). ${ }^{2}$ We began noting a temporal effect in how the relationship with God shaped stewardship in these organizations and consequently included this dimension in the coding tree (Table 3 ). We present our data and analytical interpretation next.

\section{Empirical Analysis}

\section{An Open-Systems Perspective of Faith-Led Family Businesses}

Pieper and Klein (2007, p. 301) suggest that the development or change in organizational practices explored through an open-systems perspective enables examining the "unique characteristics of a family business". This section describes the four dimensions of the six faith-led family businesses.

\section{The Business Subsystem}

Our analysis highlighted the significant influence of Christian ethics, morals, and beliefs on the way in which each business operates. In contrast to the literature reporting that the emphasis is on what a company delivers (i.e. products or services), or how it should be done, our research shows that these faith-led family businesses balance a God-centred purpose with commercial activities. Cardone (2009, p. 42) describes the critical family motto "Excellence in all things and glory to God". Similarly, Chick-fil-A (Cathy 2007, p. 123) sees as "natural the act of glorifying God through (our) work".

Interestingly, all the autobiographies acknowledge their faith-led practices as beneficial for the business now and in the future. For example, the board at Cardone describes the distinctive triple bottom line (financial, social, and spiritual), "There is no perfect balance or solution to balancing the three bottom lines... we consider the challenge in establishing the triple bottom line to have contributed to our overall business success and continued growth since 1970" (Cardone 2009, p. 20). Without success in all these dimensions, Cardone suggests that a faith-led mission is incomplete.

The autobiographies reveal that family business leaders resolve tensions by placing God at the centre of business matters. Indeed, they describe a God-led approach to productivity, employment, commercial transactions, profit,

\footnotetext{
2 Table 2 is complemented by Table S2b that can be found in the supplementary files attached to this paper.
}

and competition, describing how tensions can be resolved, expressed as "giving the business to God" (Cardone 2009, p. 21). Each autobiography includes an explanation of responding to God's calling to draw on faith-led practices to manage and grow their business, a way of relying on Christian tenets to change the purpose and focus on business practices in a God-centred perspective. In Hobby Lobby, the owner comments, "In the 80 s when the oil crisis hit we had a family meeting and my son said, 'Dad it is not you, we are depending on God"' (Green and Merrill 2010, p. 137). As another example of his faith-led spousal support, "Barbara (my wife) tried to console me, 'David, it's God's business. If He wants to take it away", (Green and Merrill 2010, p. 183).

In terms of the business subsystem, our data shows that the family business leaders describe how they create, shape, and introduce mechanisms and practices that contribute to the spiritual development of their organizational practices. This demonstrates the influence on their business, allowing their relationship with God to take precedence in decision-making.

\section{The Management Subsystem}

The management subsystem highlights the importance of the structure of the management team running the family business (Pieper and Klein 2007). Our data shows that family involvement is critical in developing top management teams, and features in all the autobiographies examined, highlighting the importance of family centred, faith-led values. For example, Scott Miller took over from Norm Miller at Interstate Batteries, Michael Cardone Jr. took over from Cardone Sr., Richard Rogers and Mary Kay's son is now the Chairman. These examples demonstrate a common approach to the management subsystem to continue their work embedded in faith-led values. Servant leadership (Sendjaya et al. 2008) is for many family members an important example of how values translate into practice in these organizations. For instance, Interstate Batteries affirms, "we are givers" (Miller and Hosier 1996, p. 142). Similarly, Chick-fil-A staff operate on value driven transformative leadership (Caldwell et al. 2012). Sendjaya et al. (2008) state the two-fold approach of expressing their faith through service to others and cultivating a sense of meaning in the workplace for those in the management subsystem. These autobiographies illustrate how this type of leadership can apply to both family and non-family members.

Logically, the autobiographies advocate recruiting non-family members with values in line with those of the organization. They describe how their faith-led approach influences recruitment. Cardone, Chick-fil-A, and Hobby Lobby all agree that being openly Christian allows them to attract and recruit highly competent individuals to work in 


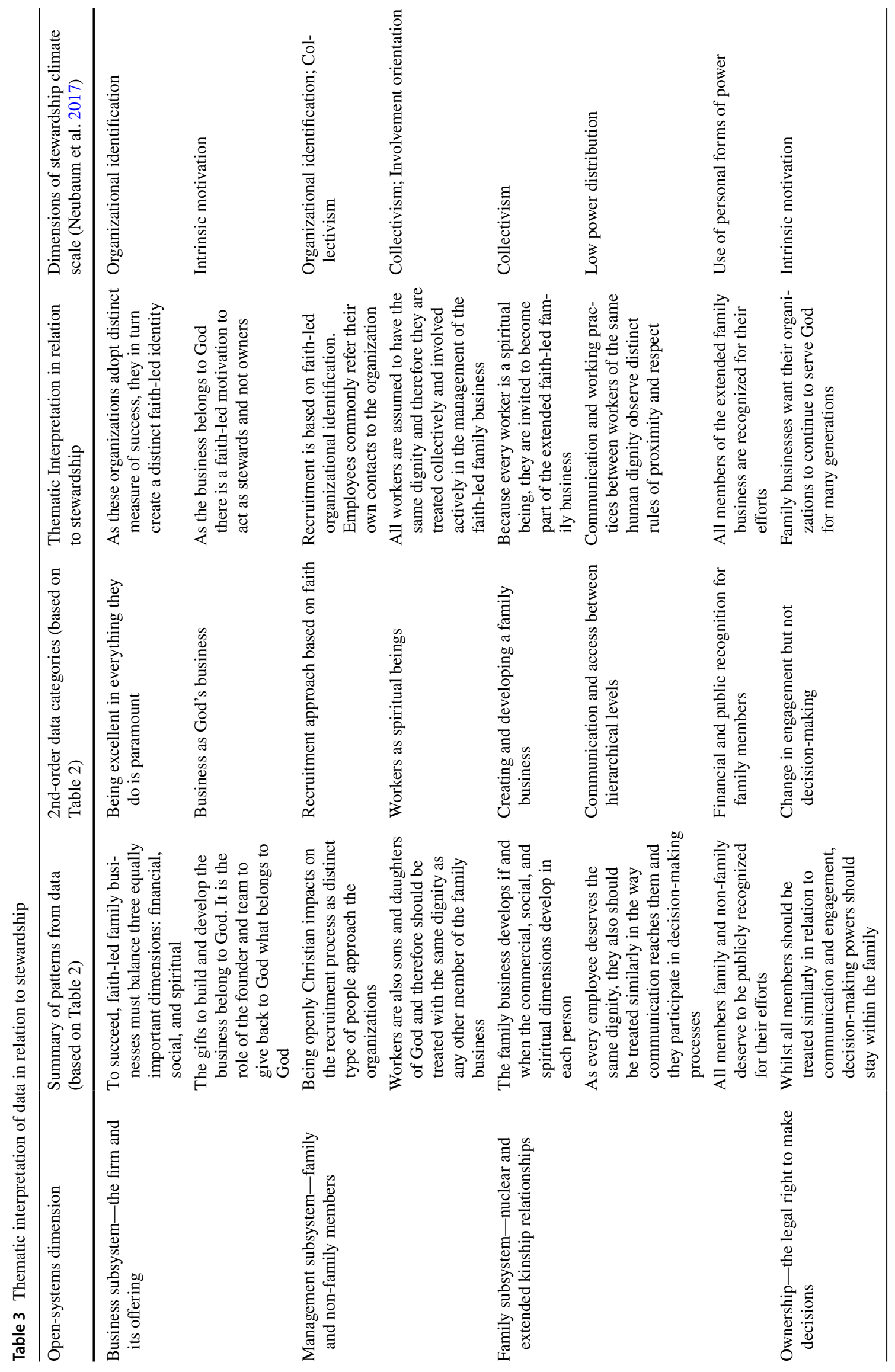


their factories, main businesses, or franchises. Hobby Lobby exemplifies this stating:

Over the last few years we've been amazed to see how many top-notch, family oriented, solid productive managers and other employees want to leave where they are and come and work for Hobby Lobby because we close on Sundays (Green and Merrill 2010, p. 138).

Such faith-related choices are crucial to selecting non-family members for various management roles. Chick-fil-A reports similar results:

Closing our business on Sunday, the Lord's day, is our way of honouring God and showing our loyalty to him... I believe God honours our decisions and sets us before unexpected opportunities to do greater work for him because of our loyalty (Cathy 2007, p. 100).

Interesting to note is how these decisions affect the workers' families and wider community. Hobby Lobby and Chick-filA's decision to close on Sundays is a critical dimension of the organization. Hobby Lobby highlights how their employees responded to this decision:

One store sent me a group letter 'It is with heartfelt thanks that we, the associates of \#147, join the thousands of other associates across the states in applauding our corporate leaders for taking the bold step in Sunday closings. We know this is a positive step for Hobby Lobby and pray that other retailers will join us in bringing back those things that are important in our lives (Green and Merrill 2010, p. 136).

The intrinsic motivation behind these significant practices is rooted in the desire to extend a God-led approach to all. This is also observable in the way these organizations discuss the importance of making a chaplain available to all staff, from family to non-family members, to enable developing their spirituality with the organization and God. Helping to see others as spiritual beings, Interstate Batteries highlights that chaplains are "available for 'light' counselling... and prepared to deal with heavy problems" (Miller and Hosier 1996, p. 134).

While the autobiographies mention the positive repercussions of implementing a God-centred approach to the business management and operations, they also describe how a faith-based approach helps manage difficult issues. Ouimet reports the efforts to reduce redundancy through a faith-led approach even when economic cycles demand the contraction of the workforce. In these circumstances, Ouimet highlights the importance of human gestures:

A simple gesture, profoundly human, and this is not always easy to do. For example a manager calls a person that has been laid off three months earlier to say hello and get the latest news; or a director decides to invite several dozen people, laid off six months to a year previously for coffee and donuts or for a simple meal just to say hello and express, in action, not words, the importance he gives to authentic communication and to each person's dignity (Ouimet and Semen 2013, p. 18)

God-led family practices in relationships with non-family members inspire the former to treat the latter as spiritual beings. The data highlight that a core feature of management in these faith-led organizations is the belief that all employees are made in the image of God and that through work they will achieve their purpose in life. According to Cardone (2009, p. 104), this approach translates into "higher quality of work, productivity, creativity, and a greater sense of personal significance". Treatment of others as spiritual beings created by God allows family business leaders to develop and shape management-related initiatives that nurture individual development and a collective purpose.

\section{The Family Subsystem}

The data also highlight the importance of ascribing a family metaphor to all employees. Cardone, reflecting on his father with whom he started Cardone Industries, contextualized this:

Dad's respect for other people was part of his faith. He believed strongly in loving one's neighbour as one's self... He saw all people as Gods children (Cardone 2009, p. 191).

In all the autobiographies, the narratives illustrate a unique relational approach to family business leadership and management deeply embedded in the importance of viewing others as members of a spiritual family (Discua Cruz 2013). Cardone exemplifies the notion of an organizational family:

... respect every person was a lesson from my father. My father treated everybody that worked for him as if they were part of the family... there was no discrimination and no regarding 'us' and 'them'... Everybody was created equal in God's sight, we just have different jobs (Cardone 2009, p. 103).

This illustrates the level of respect of management for the entire workforce. Such configuration of faith-led ideas resembles a distributed form of leadership maintained by regularly engaging in faith-centred communication. The practices described, namely, the rule of no glass towers and no reserved parking for executives (Hobby Lobby), oneto-one meetings (Interstate Batteries), and volunteering schemes (Ouimet and Cardone), indicate everyone's importance, regardless of their hierarchical level. At Ouimet and 
Cardone, volunteering in the community promotes authentic communication across levels:

Communication is based on 'being authentic yourself' or greeting others with a real interest, or, even less, out of a desire 'to manipulate people's motivation' just to improve productivity and profitability. Moreover, especially people on the lower rungs of the company, who have a great deal of intuition, are aware of the game and rapidly classify managers in three groups: 'straight shooters', 'manipulators' or 'enigmas'. It is a good thing too (Ouimet and Semen 2013, p. 19).

Finally, proof of financial and public recognition in each of the organizations is evident. Grounded in the spiritual foundation that underpins the relationship between the members of these organizations, the cases describe gestures that reinforce reciprocal behaviour among employees. Beyond the annual profit sharing scheme (present in all cases), these organizations created a number of specific awards recognizing "good" family practices. For example, Ouimet institutionalized the "Prize of Heart" for "someone who has developed a way of being and acting that communicates solidarity, help for others, and human dignity, and who does his or her work in an exemplary manner" (Ouimet and Semen 2013, p. 19). Cardone also has a number of prizes that highlight family spirit, with the most important being the "Cornerstone Award" that "celebrates the extraordinary character of the Factory Family members whose words and actions are the foundation of Cardone's objectives and values" (Cardone 2009, p. 59). Such mechanisms highlight a God-centred approach that leads all members of the organization to feeling connected.

\section{The Ownership Subsystem}

An interesting insight is how faith-led family businesses interpret ownership over time. We assumed that a faithbased approach to family business would lead to a different approach to the legal ownership of such firms. Yet, all autobiographies demonstrate no influence of religious values on the ownership structures. Despite the evidence suggesting that they have a novel and in-depth way of engaging with employees at all levels, the ownership structures remained strictly linked to the family throughout the period analysed. For example, Ouimet passed the company to his three sons, Green and his wife passed Hobby Lobby to their sons and daughters, Cardone Sr. passed the baton to Cardone Jr. who has engaged his own children and respective families in the development of the organization, Norm Miller engaged his son, Scott, who thereafter became CEO as soon as he had the appropriate experience. Such a progressive ownership structure is in line with the reported findings on family business ownership. We found no evidence of ownership distributed to members of the extended spiritual family in the autobiographies we examined.

\section{Discussion}

\section{A Faith-Led Open-Systems Perspective of Stewardship}

The previous section described the relevant subsystems that form a family business, including the personal, cultural, and economic influences on the individual members of the family business with founders that integrate the Christian faith. Our work demonstrates practices that occur within a family business system when business leaders chooses to place God at the centre of the system alongside themselves. We have shown that a faith-led family business draws on a different conceptualization of both the business environment and the family dynamic through a change in focus in the individual actor. Indeed, our analysis suggests that family business leaders associate their position in the family firm in relationship to God as part of a spiritual kinship network often referred to as "the family of God".

This implies that for the organizations studied, the definition of family is embedded in Biblical dimensions and extends to non-family members. Such organizations and family leaders do not isolate faith-led principles from organizational dynamics, and are able to put into practice one of the core biblical tenets on kinship:

So then you are no longer strangers and aliens, but you are citizens with the saints and also members of the household of God, built upon the foundation of the apostles and prophets, with Christ Jesus himself as the cornerstone (NRSV, Ephesians 2: 19-20)

The extended family network draws on the close ties between family members but also creates a structure in which all associates become part of the relational dynamic in harmony with economic motivations. In this regard, our data shows that faith-led behaviours find ways to integrate deeply held values and an extended family perspective to create intrinsic motivation and organizational identification, key components of stewardship in family business (Neubaum et al. 2017). We show here that it is through their relationship with God that faith-led practices emerge and stewardship occurs and gains form over time. Our subsystems analysis supports the view that,

The values, intentions, motivations and skills of the individual determine the actions and behaviours of the individual solely or as part of a larger group (Pieper and Klein 2007, p. 307). 
Leaders are therefore able to transform organizational practices with an understanding of what God expects from them as part of an extended spiritual family and as stewards of a family business. This insight complements current understanding of stewardship (Davis et al. 2010) focused more on the role of blood links between family members within family business. By drawing on the effect that the individual's conception of his/her relationship with God has on the family business subsystems, it also extends knowledge on the open-systems perspective on family business.

Logically, this faith-led family perspective in the organization changes not only how stewardship emerges, but also how it transforms the organization over time. Indeed, the faith-led open-systems analysis enables us to show what this transformation looks like. In essence, each element functions in support of the other elements to ensure the stability and growth of the whole system grounded in Christian values, creating a dynamic collectivistic perspective (Hofstede 1984; Pieper and Klein 2007, p. 305) typical of stewardship. We show that the development of multiple dimensions of stewardship and their effect on organizational practices is rooted in a personal relationship with God. Thus, collectivism and the underpinning organizational approaches emerge from faith. Whilst the stewardship literature has linked collectivism with the values held by leaders (Hernandez 2008; Le Breton-Miller and Miller 2009), our work explicitly demonstrates that faith-led values influence organizational and leadership practices. Overall, this also suggests that the influence of religious beliefs in the organizational practices of a family business have greater repercussions than previously thought (Steingard 2005; Tracey 2012).

The open-systems analysis also unveiled practices that illustrate substantial involvement, distributed forms of power, and low power distance, which are also commonly associated with stewardship (Neubaum et al. 2017). This is especially evident in how these organizations reciprocally communicate with members, distribute responsibilities, and employ a serving logic across hierarchical levels. In turn, this creates an environment in which workers function as stewards at their own level. Our data suggest that faith-led practices not only shape the way stewardship develops, but also support the emergence of new stewards across the organization. Whilst previous research has linked the emergence of stewards to a collective and aligned desire for success (Eddleston and Kellermanns 2007), we observe that the way faith is shared across the organization influences the way stewards emerge and remain committed to the organization, regardless of their family or non-family membership.

Overall, we add to the stewardship literature by revealing how faith influences the emergence and development of stewardship in family businesses. Stewardship has been conceptualized in previous studies as deriving from the emotional connection between the family business leader and other family members (Davis et al. 2010), but our analysis shows that stewardship can also be embedded in faith-led values and behaviours. The idea that stewardship can emerge from faith extends previous stewardship studies in the psychology or sociology domains (Henssen et al. 2014; Hernandez 2012; Wade-Benzoni et al. 2008).

Our work shows several links between Christianity and theoretical perspectives that need further attention. For example, future research might examine to what extent openly Christian family firms are more interested in addressing the socioeconomic concerns of the communities they operate in compared to their own financial concerns (Dodd and Dyck 2015). Future research could also assess how (whether) Christian denominations (e.g. Catholic or Anglican) around the world (e.g. Africa, Asia, Latin America) influence family business systems. Moreover, the non-family and family members' approach to the survival of Christian family firms (Tomhave and Vopat 2018) might be further examined through comparing the agency and stewardship perspectives (Le Breton-Miller and Miller 2018).

\section{Conclusion}

How do faith-led practices in family firms affect organizational stewardship? This study reveals that stewardship in faith-led family firms originates from the founder/leader's personal relationship with God, shaping the development and diffusion of stewardship based on faith-led organizational practices in family businesses. Our research is both timely and novel. By responding to calls for more spiritual-related work within family businesses (Holt et al. 2018) and presenting a faithled understanding of stewardship based on the accounts of religious business leaders, it enriches the theoretical dialogue on the relevance of religion in family business (Le BretonMiller and Miller 2018). Further studies of autobiographies in diverse contexts might provide a more nuanced understanding of the integration of faith in family businesses around the world (Gupta and Levenburg 2010).

\section{Compliance with Ethical Standards}

Conflict of interest The authors declare that they have no conflict of interest.

Ethical Approval No procedures with human participants or animals were performed in this study.

\section{References}

Aldrich, H. E., \& Cliff, J. E. (2003). The pervasive effects of family on entrepreneurship: Toward a family embeddedness perspective. Journal of Business Venturing, 18(5), 573-596. 
Ash, M. K., \& Pendleton, Y. (2008). The Mary Kay way: Timeless principles from America's greatest woman entrepreneur. Hoboken, NJ: Wiley.

Astrachan, J. H. (2003). Commentary on the special issue: The emergence of a field. Journal of Business Venturing, 28(5), 567-572.

Astrachan, J. H. (2010). Strategy in family business: Toward a multidimensional research agenda. Journal of Family Business Strategy, 1(1), 6-14.

Beatson, A., Lings, I., \& Gudergan, S. P. (2008). Service staff attitudes, organizational practices and performance drivers. Journal of Management and Organization, 14(2), 168-179.

Bertalanffy, L. (1972). The history and status of general systems theory. Academy of Management Journal, 15(4), 407-426.

Boyle, M., \& Parry, K. (2007). Telling the whole story: The case for organizational autoethnography. Culture and Organization, 13(3), 185-190.

Cafferky, M. (2012). Management: A faith-based perspective. New Jersey: Pearson Education.

Caldwell, C., Dixon, R. D., Floyd, L. A., Chaudoin, J., Post, J., \& Cheokas, G. (2012). Transformative leadership: Achieving unparalleled excellence. Journal of Business Ethics, 109(2), 175-187.

Cardone, M. (2009). Business with soul: Creating a workplace rich in faith and values. Nashville: Thomas Nelson Inc.

Cathy, S. T. (2007). How did you do it, Truett? A recipe for success. Decatur, GA: Looking Glass Books.

Chan-Serafin, S., Brief, A. P., \& George, J. M. (2012). PerspectiveHow does religion matter and why? Religion and the organizational sciences. Organization Science, 24(5), 1585-1600.

Davis, J. H., Allen, M. R., \& Hayes, H. D. (2010). Is blood thicker than water? A study of stewardship perceptions in family business. Entrepreneurship Theory and Practice, 34(6), 1093-1116.

Davis, J. H., Schoorman, F. D., \& Donaldson, L. (1997). Toward a stewardship theory of management. Academy of Management Review, 22(1), 20-47.

Dawson, A., \& Hjorth, D. (2012). Advancing family business research through narrative analysis. Family Business Review, 25(3), 339-355.

Discua Cruz, A. (2013). Christian family businesses: Opportunities for further research. Journal of Biblical Integration in Business, 16(2), 7-28.

Discua Cruz, A. (2015). Rethinking family businesses through a Christian perspective. Faith in Business Quarterly, 17(1), 23-30.

Discua Cruz, A. (2018). Faith, family and work: A Christian perspective. In T. Ewest (Ed.), Faith and work. Advances in workplace spirituality: Theory, research and application (pp. 151-167). Charlotte, NC: Information Age Publishing.

Dodd, S. D., \& Dyck, B. (2015). Agency, stewardship, and the universal-family firm: A qualitative historical analysis. Family Business Review, 28(4), 312-331.

Eddleston, K. A., \& Kellermanns, F. W. (2007). Destructive and productive family relationships: A stewardship theory perspective. Journal of Business Venturing, 22(4), 545-565.

Ewest, T. (2015). Christian identity as primary foundation to workplace ethics. Religions: A Scholarly Journal, 2015(1), 12.

Fletcher, D. (2002). Understanding the small family business. Oxon: Routledge.

Fletcher, D. (2010). Life-making or risk taking? Co-preneurship and family business start-ups. International Small Business Journal, 28(5), 452-469.

Ford, E. W., Duncan, W. J., Bedeian, A. G., Ginter, P. M., Rousculp, M. D., \& Adams, A. M. (2003). Mitigating risks, visible hands, inevitable disasters, and soft variables: Management research that matters to managers. The Academy of Management Executive, 17(1), 46-60.
Goss, D., Jones, R., Betta, M., \& Latham, J. (2011). Power as practice: A micro-sociological analysis of the dynamics of emancipatory entrepreneurship. Organization Studies, 32(2), 211-229.

Green, D., \& Merrill, D. (2010). More than a hobby: How a $\$ 600$ start-up became America's home and craft superstore. Nashville: Thomas Nelson.

Gundolf, K., \& Filser, M. (2013). Management research and religion: A citation analysis. Journal of Business Ethics, 112(1), 177-185.

Gupta, V., \& Levenburg, N. (2010). A thematic analysis of cultural variations in family businesses: The CASE project. Family Business Review, 23(2), 155-169.

Habbershon, T. G., Williams, M., \& MacMillan, I. C. (2003). A unified systems perspective of family firm performance. Journal of Business Venturing, 18(4), 451-465.

Hamilton, E. (2006). Whose story is it anyway? Narrative accounts of the role of women in founding and establishing family businesses. International Small Business Journal, 24(3), 253-271.

Hamilton, E. (2013). Entrepreneurship across generations: Narrative, gender and learning in family business. Cheltenham: Edward Elgar.

Henssen, B., Voordeckers, W., Lambrechts, F., \& Koiranen, M. (2014). The CEO autonomy-stewardship behavior relationship in family firms: The mediating role of psychological ownership. Journal of Family Business Strategy, 5(3), 312-322.

Hernandez, M. (2008). Promoting stewardship behavior in organizations: A leadership model. Journal of Business Ethics, 80(1), 121-128.

Hernandez, M. (2012). Toward an understanding of the psychology of stewardship. Academy of Management Review, 37(2), 172-193.

Hjorth, D., \& Dawson, A. (2016). The burden of history in the family business organization. Organization Studies, 37(8), 1089-1111.

Hofstede, G. (1984). Culture's consequences: International differences in work-related values. London: Sage Publications, Inc.

Holt, D. T., Pearson, A. W., Payne, G. T., \& Sharma, P. (2018). Family business research as a boundary-spanning platform. Family Business Review, 31(1), 14-31.

Humphreys, M., Ucbasaran, D., \& Lockett, A. (2012). Sensemaking and sensegiving stories of jazz leadership. Human Relations, 65(1), 41-62.

Ibrahim, N. A., \& Angelidis, J. P. (2005). The long-term performance of small businesses: Are there differences between "Christianbased" companies and their secular counterparts? Journal of Business Ethics, 58(1-3), 187-193.

James, A. E., Jennings, J. E., \& Jennings, P. D. (2017). Is it better to govern managers via agency or stewardship? Examining asymmetries by family versus nonfamily affiliation. Family Business Review, 30(3), 262-283.

Kellermanns, F. W. (2013). Spirituality and religion in family firms. Journal of Management, Spirituality \& Religion, 10(2), 112-115.

Kepner, E. (1983). The family and the firm: A coevolutionary perspective. Organizational Dynamics, 12(1), 57-70.

Le Breton-Miller, I., \& Miller, D. (2009). Agency vs. stewardship in public family firms: A social embeddedness reconciliation. Entrepreneurship Theory and Practice, 33(6), 1169-1191.

Le Breton-Miller, I., \& Miller, D. (2018). Looking back at and forward from: Family governance and firm performance: Agency, stewardship, and capabilities. Family Business Review, 31(2), 229-237.

Litz, R. A. (2008). Two sides of a one-sided phenomenon: Conceptualizing the family business and business family as a Möbius strip. Family Business Review, 21(3), 217-236.

Lumpkin, G. T., \& Brigham, K. H. (2011). Long-term orientation and intertemporal choice in family firms. Entrepreneurship Theory and Practice, 35(6), 1149-1169.

Lynn, M. L., \& Wallace, D. (2001). Doing business with the Hebrew bible: A hermeneutic guide. Journal of Biblical Integration in Business, 6, 9-40. 
Mabey, C., Conroy, M., Blakeley, K., \& de Marco, S. (2017). Having burned the straw man of Christian spiritual leadership, what can we learn from Jesus about leading ethically? Journal of Business Ethics, 145(4), 757-769.

Madison, K., Holt, D. T., Kellermanns, F. W., \& Ranft, A. L. (2016). Viewing family firm behavior and governance through the lens of agency and stewardship theories. Family Business Review, 29(1), 65-93.

Martins, E. C., \& Terblanche, F. (2003). Building organizational culture that stimulates creativity and innovation. European Journal of Innovation Management, 6(1), 64-74.

Mathias, B. D., \& Smith, A. D. (2016). Autobiographies in organizational research using leaders' life stories in a triangulated research design. Organizational Research Methods, 19(2), 204-230.

Melin, L., Nordqvist, M., \& Sharma, P. (2014). The SAGE handbook of family business. Newcastle upon Tyne: SAGE.

Miller, N., \& Hosier, H. K. (1996). Beyond the norm: The amazing story of a traveling salesman who went the extra mile to become chairman of Interstate batteries. Nashville: Thomas Nelson Incorporated.

Neubaum, D. O., Thomas, C. H., Dibrell, C., \& Craig, J. B. (2017). Stewardship climate scale: An assessment of reliability and validity. Family Business Review, 30(1), 37-60.

Ouimet, J.-R., \& Semen, Y. (2013). Everything has been loaned to you: The biography of a transformational CEO. Staten Island: St. Pauls.

Paterson, T. A., Specht, D., \& Duchon, D. (2013). Exploring costs and consequences of religious expression in family businesses. Journal of Management, Spirituality \& Religion, 10(2), 138-158.

Patton, M. Q. (2002). Qualitative research and evaluation methods. Thousand Oaks, CA: SAGE.

Pieper, T. M., \& Klein, S. B. (2007). The bullseye: A systems approach to modelling family firms. Family Business Review, 20(4), 301-319.

Reveley, J. (2010). Using autobiographies in business history: A narratological analysis of Jules Joubert's shavings and scrapes. Australian Economic History Review, 50(3), 284-305.

Rossouw, G. J. (1994). Business ethics: Where have all the Christians gone? Journal of Business Ethics, 13(7), 557-570.

Schlippe, A., \& Frank, H. (2013). The theory of social systems as a framework for understanding family businesses: Theory of social systems and family businesses. Family Relations, 62(3), 384-398.

Schwartz, M. S. (2006). God as a managerial stakeholder? Journal of Business Ethics, 66(2-3), 291-306.

Segal, L., \& Lehrer, M. (2012). The institutionalization of stewardship: Theory, propositions, and insights from change in the Edmonton public schools. Organization Studies, 33(2), 169-201.
Sendjaya, S., Sarros, J. C., \& Santora, J. C. (2008). Defining and measuring servant leadership behaviour in organizations: Servant leadership behaviour in organizations. Journal of Management Studies, 45(2), 402-424.

Smith, R. (2005). The fabrication of entrepreneurial fable: A biographical analysis. The Journal of Private Equity, 8(4), 8-19.

Smith-Acuna, S. (2011). Systems theory in action: Applications to individual, couple, and family therapy. Hoboken: Wiley.

Sorenson, R. L. (2013). How moral and social values become embedded in family firms. Journal of Management, Spirituality \& Religion, 10(2), 116-137.

Steingard, D. S. (2005). Spiritually-informed management theory toward profound possibilities for inquiry and transformation. Journal of Management Inquiry, 14(3), 227-241.

Tomhave, A., \& Vopat, M. (2018). The business of boycotting: Having your chicken and eating it too. Journal of Business Ethics, 152(1), 123-132.

Tracey, P. (2012). Religion and organization: A critical review of current trends and future directions. The Academy of Management Annals, 6(1), 87-134.

Wade-Benzoni, K. A., Hernandez, M., Medvec, V., \& Messick, D. (2008). In fairness to future generations: The role of egocentrism, uncertainty, power, and stewardship in judgments of intergenerational allocations. Journal of Experimental Social Psychology, 44(2), 233-245.

Weaver, G. R., \& Agle, B. R. (2002). Religiosity and ethical behavior in organizations: A symbolic interactionist perspective. Academy of Management Review, 27(1), 77-97.

Westley, F., \& Mintzberg, H. (1989). Visionary leadership and strategic management. Strategic Management Journal, 10(S1), 17-32.

Wong, N. D., Smith, A., \& Popp, A. (2018). Religiosity, emotional states, and strategy in the family firm: Edm. Schluter \& Co Ltd., 1953-1980. Entreprises et Histoire, 91, 98-125.

Zahra, S. A., Hayton, J. C., Neubaum, D. O., Dibrell, C., \& Craig, J. (2008). Culture of family commitment and strategic flexibility: The moderating effect of stewardship. Entrepreneurship Theory and Practice, 32(6), 1035-1054.

Publisher's Note Springer Nature remains neutral with regard to jurisdictional claims in published maps and institutional affiliations. 